\title{
Action learning in partnership with Landcare and catchment management groups to support increased pasture sowings in southern inland Queensland
}

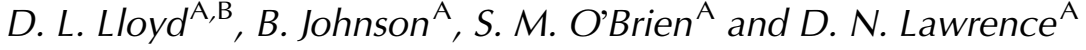 \\ ${ }^{A}$ Department of Primary Industries and Fisheries, PO Box 102, Toowoomba, Qld 4350, Australia. \\ ${ }^{\mathrm{B} C}$ Corresponding author. Email: david.Iloyd@dpi.qld.gov.au
}

\begin{abstract}
The incorporation of sown pastures as short-term rotations into the cropping systems of northern Australia has been slow. The inherent chemical fertility and physical stability of the predominant vertisol soils across the region enabled farmers to grow crops for decades without nitrogen fertiliser, and precluded the evolution of a crop-pasture rotation culture. However, as less fertile and less physically stable soils were cropped for extended periods, farmers began to use contemporary farming and sown pasture technologies to rebuild and maintain their soils. This has typically involved sowing long-term grass and grass-legume pastures on the more marginal cropping soils of the region.

In partnership with the catchment management authority, the Queensland Murray-Darling Committee (QMDC) and Landcare, a pasture extension process using the LeyGrain ${ }^{\mathrm{TM}}$ package was implemented in 2006 within two Grain \& Graze projects in the Maranoa-Balonne and Border Rivers catchments in southern inland Queensland. The specific objectives were to increase the area sown to high quality pasture and to gain production and environmental benefits (particularly groundcover) through improving the skills of producers in pasture species selection, their understanding and management of risk during pasture establishment, and in managing pastures and the feed base better. The catalyst for increasing pasture sowings was a QMDC subsidy scheme for increasing groundcover on old cropping land. In recognising a need to enhance pasture knowledge and skills to implement this scheme, the QMDC and Landcare producer groups sought the involvement of, and set specific targets for, the LeyGrain workshop process. This is a highly interactive action learning process that built on the existing knowledge and skills of the producers.

Thirty-four workshops were held with more than 200 producers in 26 existing groups and with private agronomists. An evaluation process assessed the impact of the workshops on the learning and skill development by participants, their commitment to practice change, and their future intent to sow pastures.

The results across both project catchments were highly correlated. There was strong agreement by producers $(>90 \%)$ that the workshops had improved knowledge and skills regarding the adaptation of pasture species to soils and climates, enabling a better selection at the paddock level. Additional strong impacts were in changing the attitudes of producers to all aspects of pasture establishment, and the relative species composition of mixtures.

Producers made a strong commitment to practice change, particularly in managing pasture as a specialist crop at establishment to minimise risk, and in the better selection and management of improved pasture species (particularly legumes and the use of fertiliser). Producers have made a commitment to increase pasture sowings by $80 \%$ in the next 5 years, with fourteen producers in one group alone having committed to sow an additional 4893 ha of pasture in 2007-08 under the QMDC subsidy scheme.

The success of the project was attributed to the partnership between QMDC and Landcare groups who set individual workshop targets with LeyGrain presenters, the interactive engagement processes within the workshops themselves, and the follow-up provided by the LeyGrain team for on-farm activities.
\end{abstract}

\section{Introduction}

The southern grain belt of Queensland, Australia, is an area extending northwards from the border with New South Wales to the town of Roma within the northern catchments of the Murray-Darling Basin (latitudes 26-28 ${ }^{\circ}$ ). Annual rainfall ranges from 490 to $660 \mathrm{~mm}$ (Clewett et al. 2003), with about two-thirds falling during the summer months (October to March). Winter rainfall (April to September) is also effective, and winterand summer-growing crop and pasture species are utilised in production systems. Farms in this region tend to be larger and are cropped less intensively than those in the southern states and Western Australia (Ewing and Flugge 2004). Thus, large areas are devoted to livestock production. The value of sown pastures and crops used for grazing and conservation in the southern grain belt of Queensland is approximately A $\$ 0.83$ billion/year, mainly from beef cattle, at least equalling the value of field crops (Department of Employment Economic Development and Innovation 2009; M. Gout and S. M. Jones, pers. comm.).

The traditional cropping soils are the alkaline, vertisol clay soils that vary widely in soil profile chemistry, particularly 
sodicity (Lloyd et al. 2007a). They have a high plant available water capacity (160-260 mm) (Dalgleish and Foale 1998), are physically stable, were nitrogen fertile and have generally sustained a cropping monoculture that now involves both summer- and winter-growing grain and pulse crops. More recently, woodland clay-loam to loamy soils of lower fertility (Lloyd et al. 2007a), poorer structural stability and lower water holding capacity, and with a lesser cropping capability, have been cropped using similar rotation systems. Long periods of cropping have caused the fertility (Dalal and Mayer 1986) and general health of cropping soils to decline, at a cost of more than A $\$ 450$ million/year (M. Probert, pers. comm.) to the grain industry.

Well managed pastures are critical components of mixed farming systems, building resilience into both the profitability and environmental sustainability of those systems (Lloyd et al. 2007b). Pastures have been traditionally sown as mid- to longterm grass-legume phases (often called 'permanent pastures'), generally on arable soils of lesser cropping capability. The use of planned, short- to medium-term, crop-pasture rotation systems (Puckridge and French 1983; Reeves 1987) on mixed farms in southern Queensland is low, less than one-tenth of that in southern and Western Australia. Lablab (Lablab purpureus) and lucerne (Medicago sativa) are sometimes used to provide quality forage, soil nitrogen and as a break crop to combat crop disease.

The integration of pastures into farming systems is complex (Lloyd 2004). The slow pace of adoption of sown pastures is typical of major system change (Llewellyn et al. 2005). It is a function of farmers' perceptions of 'what works for them', their willingness and ability to manage risk in a complex enterprise and a lack of conviction of the benefit of pastures to the whole farming system. More specifically, farmers in the region identified impediments to pasture adoption (Blacket and Hamilton 1992) as: (i) relative profitability of grain and livestock products; (ii) their limited knowledge of pasture technologies leading to risk of failure during pasture establishment; (iii) soil compaction by livestock on cropping land; (iv) weed control during the pasture phase; (v) limited nitrogen addition to the soil by pasture legumes; (vi) deep rooting pasture plants (particularly lucerne) drying soil profiles; (vii) bloat caused by legumes; and (viii) livestock management, a social constraint (Vanclay 2004) identified by farmers more accustomed to cropping. More recently, the QMDC catchment management authority in southern Queensland identified the need to increase the area of arable land sown to pasture to improve soil condition for subsequent crops, and to increase ground cover to enhance environmental benefits (Littleboy et al. 1989). In relation to groundcover, the QMDC offered subsidies, paid on the successful implementation of approved development plans, to farmers to encourage pasture resowing. The provision of subsidies stimulated an interest in returning 'old' cultivation, often on land of marginal cropping capability, to a pasture phase. However, this, per se, did not provide the knowledge and skills that many producers required to implement pastures successfully.

Thus, a partnership evolved between QMDC and Landcare producer groups and, through the national Grain and Graze initiative, the providers and presenters of the participatory action learning package LeyGrain (Lloyd et al. 2007b), who responded to the prioritised need to deliver pasture extension during the inception of the Grain \& Graze project. Analogous processes involving a Landcare approach have been successful in engaging farming communities to adopt changed practices in developing countries (Cramb et al. 2007). LeyGrain is a facilitated action learning workshop and on-farm process designed to help groups of producers understand the benefits and needs for short- and longer-term pastures in their farming systems and to develop the skills to manage the pasture phase. Action learning processes provide groups of farmers with options that are easy to test in semicommercial situations on-farm that provide credible outcomes (Pannell et al. 2006) for commercial scale adoption. Action learning aims to combine existing knowledge with peoples' emergent understandings of complex issues (Revans 1982). Within this framework, Revans (1997) describes learning $(L)$ as the sum of existing programmed instruction $(P)$ and questioning insight $(Q)$, that is $L=P+Q$. Combining scientific knowledge with the direct experiences of farmers in the context of continuous improvement is the basis for LeyGrain.

This paper outlines the structure of the LeyGrain package and describes the impact of its delivery in southern Queensland on the knowledge and skills of producers, practice change and new areas of pastures sown, and relates this to other successful extension processes.

\section{Materials and methods}

\section{The LeyGrain package}

LeyGrain presents a strategic overview of the rationale for pastures in mixed farming systems and their subsequent management. It deals with the critical issues that farmers confront at the interface between establishing pastures on arable land and returning pastures to crops, and in managing pastures to maximise livestock production, ground cover and soil fertility benefits.

LeyGrain comprises four sections in a logical sequence:

Section 1: 'Benefits and profitability' outlines the production and environmental benefits and challenges of incorporating pasture phases into arable systems e.g. soil $\mathrm{N}$ and $\mathrm{C}$, legumes and the $\mathrm{N}$ cycle, soil physical issues, effects on pests, diseases and weeds, effects on soil structure, infiltration, erosion and water leakage through profiles. In this section, a whole farm profitability and risk analysis model, PRECaPS (Strahan and Scott 2004; Lloyd et al. 2007b), is used to compare the profitability of implementing a range of crop and crop-pasture systems using producer data or data obtained from other sources. PRECaPS is created in MSExcel and based on dynamic gross margin worksheets for most cropping and livestock enterprises in the northern grain belt. It provides for new enterprises to be included, accounts for fixed and variable costs and, while based on average data, allows for a range of cost and production variables to be applied probabilistically to account for economic risk in the introduction of a new enterprise into the system.

Section 2: 'Planning the pasture phase' deals with critical issues at the interface between cropping and pasture phases e.g. paddock selection, the duration of the pasture phase, species selection and establishment, and planning pasture phases in the rotation. 
Section 3: 'Managing pasture and livestock production' develops principles and methodologies for targeting animal production to high value markets through understanding animal nutrition and feed quality, and feed year planning and feed budgeting principles. It also deals with pasture and animal management and some antinutritional issues associated with pastures.

Section 4: 'Planning the return to crop' addresses key issues at the pasture/crop interface, dealing with methods for and timing of the removal of pasture, soil nitrogen and water replenishment, and planning subsequent rotation sequences.

Each section has been developed with an emphasis on principles rather than 'recipes' and can provide a focus for a single workshop. However, participatory workshops have been frequently customised to focus on discrete modules within and between these sections e.g. pasture establishment, pasture species selection, pasture species selection and management. Workshops are designed to be followed by ongoing, on-farm action learning activities.

\section{The workshop process}

In partnership with the QMDC and 26 catchment management and Landcare producer groups, LeyGrain workshops were delivered throughout the southern Queensland grain belt from Stanthorpe $\left(28^{\circ} 39^{\prime} \mathrm{S}, 151^{\circ} 56^{\prime} \mathrm{E}\right)$ in the south-east to Nindigully $\left(28^{\circ} 28^{\prime} \mathrm{S}, 148^{\circ} 49^{\prime} \mathrm{E}\right)$ in the south-west and Mitchell $\left(26^{\circ} 29^{\prime} \mathrm{S}\right.$, $147^{\circ} 59^{\prime} \mathrm{E}$ ) in the north-west (Appendix 1). Twelve of these groups are located within the Maranoa-Balonne catchment and 14 in the Border Rivers catchment. LeyGrain was delivered following invitation by group coordinators, based on their assessment of the needs of the group. Initially, workshops were presented in logical sequence beginning with Section 1, the benefits and profitability of pastures in farming systems. However, the process evolved quickly to one where the workshop sections or components presented were selected by groups according to their needs. A total of 34 workshops, 16 in Maranoa-Balonne and 18 in Border Rivers, were delivered on components of sections 1, 2 and 3 of the package between February 2006 and February 2008 , with 26 of these focusing on pasture species and establishment. The number of producers at each workshop ranged from 3 to 23, with a mean and median number of 11 . In addition, one workshop encompassing the whole package was presented to a group of nine private agronomists in the Border Rivers catchment. Most private agronomists in both catchments are cropping agronomists and these participants have sought training in pasture development and management.

The workshop process, presented interactively using MS PowerPoint, drew heavily on the knowledge of participants, and used group processes to reflect on and learn from their mutual experiences (Lewin 1947). The presenters' roles were to value-add to the existing knowledge. A guided learning process was used to help participants navigate and understand the logic of each workshop issue (Lawrence et al. 2000). The challenge for facilitators and presenters was to match the levels of detail to participants' initial knowledge for proximal development (Billett 2001; Lawrence 2006), and develop the necessary skills to better use pastures on their farms.

On-farm activities and field days were designed to explore the relative performance of a range of pasture species and fertiliser treatments in different environments (Appendix 2). These were curtailed by the extremely dry or drought conditions that were experienced during the duration of the project.

In addition, LeyGrain presenters assessed the pasture development plans of 19 farmers in Border Rivers (five groups) and one in Maranoa-Balonne for their impact on ground cover to gain approval for the QMDC subsidy.

\section{Evaluation and analysis}

Groups in both catchments used the same survey template to assess the impact on and knowledge and skills gained by farmers attending LeyGrain workshops. Seven broad aspects of participants' knowledge and skills were assessed: the research, development and extension process; the workshop process; species selection; pasture establishment; pasture and animal management; managing the mixed farm; and the impact on the 'bottom line' (Table 1).

The evaluation surveys (Appendix 3) were completed after each workshop. The responses were made on 5-point Likert scales $(1=$ strongly disagree; $5=$ strongly agree $)$ and translated to an impact rating of strong, moderate or low (strong impact $=5$; moderate impact $=4$; low impact $=3,2$ or 1 ), and an overall average impact rating where values $>4.0$ represented high impact and values $>3.0$ but $<4$ represented moderate impact. A betweenregion correlation was carried out between the overall impact ratings for the 27 attributes, to identify the similarity between regions. Summary data were collated and calculated using the Statistical Package for Social Scientists (SPSS 16.0 for Windows).

By using a series of questions within the survey, intended practice change attributed to the workshop and the change in the areas of pasture sown during the 5 years before the workshop, and the likely impact on the area of pasture to be sown in the following 5 years, were also assessed. Participants were asked to respond in their own words to those questions.

\section{Results}

Impact on knowledge and skills

LeyGrain workshops have made a strong, positive contribution to the knowledge and skills of participants (Table 1) with the overall impact of the workshops in the Maranoa-Balonne and Border Rivers catchments being highly correlated $(r=0.61 ; P<0.001$; $n=27$ ).

The strongest specific impacts for participants were that LeyGrain workshops:

(1) were a good investment of Research and Development Corporation monies;

(2) created a participatory learning environment;

(3) increased knowledge about pasture species;

(4) helped producers understand seed quality.

Moderate to strong impacts were made by all workshops associated with pasture species selection and pasture establishment. The least, though nevertheless moderately strong, impacts were made in helping to improve farming practices, in assisting producers understand the requirements for feed of their livestock classes, in influencing the 'bottom line' and in improving the way in which research, development 
Table 1. Percentage of participants in the Maranoa-Balonne (MB) and Border Rivers (BR) catchments rating the impact of LeyGrain workshops on their knowledge and skills as strong (rating 5), moderate (rating 4) and low (rating 1-3), together with an overall average rating (1-5)

The numbers of statistically valid responses in each catchment are in parentheses (Maranoa-Balonne and Border Rivers, respectively)

\begin{tabular}{l}
\hline Issue \\
\hline \\
Good investment of Research and Development \\
Corporation funds $(104,154)$ \\
Improved how research, development \\
and extension is done $(8,12)$ \\
Provided opportunities to participate $(104,177)$ \\
Helped learn from others $(103,176)$ \\
Strong impact on learning $(102,176)$ \\
Helped answer my pasture issues $(19,70)$ \\
Helped understand pasture development \\
principles $(10,16)$
\end{tabular}

Improved knowledge of species $(85,106)$ Improved ability to select suitable grasses $(85,106)$ Improved ability to select suitable legumes $(84,105)$ Improved ability to examine alternative options and mixes $(102,135)$

Improved ability to improve pasture establishment $(91,120)$ Improved skills in reducing establishment risk $(84,105)$

Helped understand seed quality $(85,106)$

Provided information on how to sow $(84,105)$

Helped understand and assess pasture quality $(17,46)$ Improved ability to understand animal requirements $(9,11)$ Improved ability to plan feed year requirements $(9,33)$ Improved ability to plan feed budgets $(9,32)$

Improved ability to manage pastures $(18,66)$ Improved ability to manage pasture systems $(10,14)$ Improved ability to manage animals $(9,32)$

Helped improve farming practice $(92,118)$

Helped improve whole farm management $(10,14)$

Provided skills to develop crop/pasture rotations $(9,14)$

Helped improve profitability $(10,36)$

Helped improve sustainability $(10,23)$
Strong impact

MB BR Moderate impact

MB BR
Rating value

Research, development and extension process

$\begin{array}{llll}52 & 54 & 45 & 44\end{array}$

$0 \quad 25$

Workshop process

$\begin{array}{llll}58 & 59 & 41 & 39\end{array}$

$41 \quad 42$

$46 \quad 36$

$32 \quad 40$

$30 \quad 31$

Species selection

$\begin{array}{rrrrrrrr}59 & 59 & 41 & 40 & 0 & 1 & 4.6 & 4.5 \\ 34 & 45 & 59 & 51 & 7 & 4 & 4.3 & 4.4 \\ 33 & 41 & 56 & 53 & 11 & 6 & 4.2 & 4.4 \\ 26 & 40 & 66 & 50 & 9 & 10 & 3.8 & 4.5\end{array}$

Pasture establishment

$\begin{array}{rrrrrrrr}35 & 46 & 52 & 46 & 13 & 9 & 4.2 & 4.4 \\ 33 & 43 & 58 & 45 & 8 & 12 & 4.3 & 4.3 \\ 60 & 61 & 38 & 35 & 2 & 4 & 4.6 & 4.6 \\ 32 & 28 & 61 & 58 & 7 & 14 & 4.3 & 4.1\end{array}$

Pasture and animal management

$\begin{array}{rr}29 & 33 \\ 11 & 0 \\ 22 & 18 \\ 22 & 19 \\ 22 & 36 \\ 0 & 43 \\ 22 & 22\end{array}$

Managing the mixed farm

\begin{tabular}{|c|c|c|c|c|c|c|c|}
\hline 17 & 19 & 58 & 53 & 23 & 24 & 3.9 & 3.9 \\
\hline 0 & 29 & 70 & 64 & 30 & 7 & 3.7 & 4.2 \\
\hline 0 & 21 & 78 & 64 & 22 & 14 & 3.8 & 4.1 \\
\hline \multicolumn{8}{|c|}{ The bottom line } \\
\hline 0 & 31 & 50 & 50 & 50 & 19 & 3.5 & 4.1 \\
\hline 0 & 26 & 90 & 52 & 10 & 22 & 3.9 & 4.0 \\
\hline
\end{tabular}

and extension was carried out. While the numbers of participants enabled a statistically valid statement of impact, the numbers of participants who responded to particular questions varied, reflecting the variable number of workshops that were targeted at those subject areas.

\section{Intended changes in practice}

The surveys assessed the intent of producers to change practice through the question, 'After the LeyGrain workshop, what will you do differently?' (Appendix 3). Thus, the outcome is notional, but reflects the key areas in which the LeyGrain process is improving management decisions. Of the 178 responses in both project areas that were collated according to the skills issues listed in Table 1, the following six accounted for $94 \%$ of the practice change that producers intend to implement:

(1) Change establishment practice to better minimise risk $(27.7 \%)$;

(2) Select pasture species adapted to the soils/climate of the paddock $(22.9 \%)$

(3) Focus on legumes - select adapted cultivars and employ better management (19.5\%);

(4) Ensure that seed purchased meets germination standards $(10 \%)$;

(5) Consider using fertiliser (7.4\%);

(6) Plan the whole pasture phase better $(6.5 \%)$. 


\section{Evidence of change on farms}

Five years ago, 60 responding producers in the Maranoa-Balonne catchment and 93 producers in the Border Rivers catchment had sown 768 and $376 \mathrm{ha} /$ producer, respectively (Table 2). At the time of the workshop, these areas had increased to 1113 ha/producer (45\% increase) and $617 \mathrm{ha} /$ producer $(64 \%$ increase), respectively.

In the next 5 years, those producers indicated their intention to expand their pasture sowings to $1912 \mathrm{ha}$ /producer in the Maranoa-Balonne catchment and 1190 ha/producer in the Border Rivers catchment. This equals a further increase of $72 \%$ and $93 \%$, respectively.

Survey responses confirm that participants' new knowledge and skills will impact immediately on an increasing area of sown pastures in the region and will also be a direct contributor to the greater areas of pastures that will be planted during the next 5 years.

Producer feedback confirms that these intentions are being put into practice (see 'Discussion'). Property action plans for pasture sowings under the QMDC subsidy scheme, assessed by the LeyGrain team and developed by producers in the Talwood group $\left(28^{\circ} 29^{\prime} \mathrm{S}, 144^{\circ} 28^{\prime} \mathrm{E}\right)$ who attended LeyGrain workshops, resulted in 4893 ha being committed for sowing in summer 2007-08.

\section{Discussion}

In farming systems, component change can occur quickly, for example in the adoption of new crop and pasture cultivars. However, broad shifts in farming systems practice are slow, evolutionary and influenced strongly by economic as well as biophysical factors (Collinson 2000). For example, the move from full cultivation to zero till in cropping systems in Queensland has been generational, sporadic and evolving with the provision of ongoing information derived from a wide range of research (Thomas et al. 2007). The LeyGrain extension process employed with Landcare and catchment management groups in the Maranoa-Balonne and Border Rivers catchments in this study did not set out to change the farming system where pastures are used mainly as long-term phases, but to increase the area sown to both short- and long-term pasture. This increase in pasture area will increase the groundcover and natural resource outcomes sought by QMDC in the region, while enhancing soil nitrogen and carbon levels and crop production (e.g. Dalal et al. 2004a, 2004b; Strong et al. 2006).

LeyGrain has a strong biophysical and economic base and applies participatory group action learning principles that have developed the capacity of the participants in this project, elements that have also been successful in group processes in developing

Table 2. Area sown to pasture in 2002, 2007 and predicted for 2012 in the Maranoa-Balonne and Border Rivers catchments The number of responding producers is in parentheses

\begin{tabular}{ccc}
\hline Year & \multicolumn{2}{c}{ Area sown to pasture (ha/producer) } \\
& Maranoa-Balonne & $376(93)$ \\
2002 & $768(60)$ & $617(92)$ \\
2007 & $1113(56)$ & $1190(83)$ \\
2012 & $1918(53)$ & \\
\hline
\end{tabular}

countries (Cramb et al. 2007; Winter and Doyle 2008). The process, involving partnership with and invitation by QMDC, Landcare and catchment management groups, has ensured that producers with a genuine interest in pasture development have been targeted viz. 'the success of the process has been the result of genuine and effective partnerships between QMDC, Landcare and the LeyGrain delivery team' (S. Cook, QMDC Grazing Lands Coordinator, pers. comm.).

Twenty-six of 34 LeyGrain workshops focussed on pasture species and pasture establishment. These issues were identified by producers themselves as constraining the sowing of pastures. Thus, producers' perceptions rather than the process itself were allowed to dictate the curriculum presented (Llewellyn et al. 2005), and the success in empowering producers through providing knowledge and developing skills is evidenced by feedback from three producer groups (J. Betts, Goondoola group; M. Redgen, Yalebone Creek group; S. Wilkins, Toobeah group, pers. comm.) viz. 'the process and content was relevant and presented in a manner that farmers with different levels of experience could understand, interact and gain confidence in implementing pastures; the workshops reinforced and broadened our understanding of pasture cultivar selection; we developed strategies to minimise limitations and risks in pasture establishment'. Two of these farmers have proceeded to adoption, one sowing 400 ha and the other 1700 ha of pasture during their involvement in the LeyGrain process. A third has commenced large scale trial sowings of the pasture legume caatinga stylo (Stylosanthes seabrana), confirming the strong relationship between adoption and the ability to trial new technologies identified during the process (Pannell et al. 2006). Thus, the immediate increase in the area sown to pastures by the Talwood group and the notional increases in sowings promised by other group participants are positive responses in adoption that can be associated with the LeyGrain process.

The overall impact of LeyGrain was significantly correlated across the Maranoa-Balonne and Border Rivers catchments, which are contiguous with similar soils and climates. The dryland farming systems in both regions are based on the same crops, pastures and practices. Thus, the impact correlation was not unexpected.

The QMDC initiative to provide conditional funding to sow 80000 ha of land to pasture to reverse the ongoing decline in soil conditions owing to cropping (S. Cook, pers. comm.) was a significant contributor to the stimulus to the new and notional pasture sowings identified by producers during the LeyGrain process. Following the drought of the early to mid 2000s, producers had limited funds for development and this subsidy scheme was attractive and influential in stimulating change. In this context, LeyGrain was a critical enabler that helped participants build the understanding and skills to make the desired changes on their properties. The producers recognised the need for pasture technology enhancement by requesting the presentation of LeyGrain workshops and then selected critical components to enhance their knowledge and skills. The success of this synergy, measured by new pasture sowings, has been a result of the genuine and effective partnership described previously (S. Cook, pers. comm.). LeyGrain presenters further contributed to this synergy 
providing specialist involvement in the approval process for development plans submitted by producers seeking subsidy. The specific increase in pasture sown by the Talwood group in 2007-08 was driven by the environmental concerns of producers who had been farming marginal cropping soils in a marginal climate. The commitment to sow larger areas to pasture from 2007-12 was driven by producers recognising that cropping had created significant environmental challenges, particularly on marginal soils in marginal cropping environments.

The social implication of the empowerment of producers results in their recognition within communities as leaders of technological change. Through LeyGrain, leading producers have gained the confidence to successfully challenge seed companies to make the following changes to reduce the risk of poor pasture establishment and persistence:

(1) Provide seed of caatinga stylo (Stylosanthes seabrana) that is more germinable (with less hard-seed) for use in southern Queensland farming systems;

(2) Provide mixes of pasture seed to suit their environment at the paddock level, rather than accepting proprietary blends;

The success of the LeyGrain process can be attributed to several issues:

(1) Genuine partnerships developed between LeyGrain presenters, Landcare and QMDC group coordinators, and the QMDC Grazing Lands Coordinator;

(2) Groups who collectively identified a need to enhance their knowledge and skills with pastures that led to the invitation to present the LeyGrain process and then set the curriculum for each workshop to meet their specified needs;

(3) The engagement process between presenters with knowledge and skills in pasture technology, and small groups of producers viz. "the workshops were presented in a manner that all farmers of all levels of experience could understand, interact and gain confidence in implementing LeyGrain strategies' (J. Betts, pers. comm.) and 'the presenters were both knowledgeable and approachable' (M. Redgen, pers. comm.). Groups with an average of 11 participants resulted in effective interactive processes;

(4) A workshop process that identified and effectively utilised existing producer knowledge, followed by value-adding by the presenters;

(5) Follow-up, particularly in the development of on-farm activities, after the workshops themselves viz. 'the followup by LeyGrain staff has been invaluable' (J. Betts, pers. comm.), 'we continue to benefit by their ongoing input' (M. Redgen, pers. comm.), 'presenters provided back-up support in telephone calls and property visits' (S. Wilkins, pers. comm.) and 'with the presenters, the group is planning on-farm trials of different grasses and legumes' (K. Johnson, Donnybrook group, pers. comm.)

Dry conditions limited on-farm activities within the LeyGrain process. Although the workshops were effective and significant areas of pasture were sown or nominated for sowing, adoption would have been enhanced by a greater on-farm focus viz. more trials and demonstrations, supported by field days at regular intervals to engage a wider audience. In the future, the
LeyGrain process will have an even greater focus on on-farm activities to build on the understanding that has been developed and support on-ground change.

Adoption is the critical issue in any process of technology transfer. We believe that research, development and extension with pastures in farming systems could be conducted within a strategic extension framework such as LeyGrain, to engage larger numbers of producers in a process of continuous learning from research to adoption.

\section{Conclusion}

In the early 1990s, producers identified several issues affecting their capacity to change their farming system, particularly to incorporate pastures within their system of crop rotation, including difficulties with pasture establishment and management, and with the management of livestock in integrated crop-livestock systems (Blacket and Hamilton 1992). Nevertheless, they agreed that pasture-crop systems have benefits that include reduced input costs, enhanced soil fertility and grain production together with benefits for natural resource management.

With continually changing terms of trade and the recognition of environmental threats posed by continuous cultivation, the delivery of the LeyGrain pasture extension process has helped producers to understand and assess the role and successful implementation of sown pastures, to develop skills to implement practice change, and to increase the area sown to pasture in 2007-08 (aided by the provision of QMDC subsidies) and notionally during the next 5 years.

The success of LeyGrain can be attributed to this structuring of technical information, the choice of a workshop curriculum by producers based on need, the expert delivery process to help participants build their own knowledge from this information (and make decisions on their own farm), the interactive process of engagement with producer groups that recognised their existing knowledge, follow-up activities with those groups and, above all, the enduring partnership developed with QMDC and Landcare to facilitate the process. Follow-up activities are now underway to support producers in implementing their intended pasture sowings across the region.

\section{References}

Billett S (2001) Co-participation at work: affordance and engagement. In 'Sociocultural perspectives on learning through work: new directions for adult and continuing education, no. 92'. (Ed. T Fenwick) pp. 63-72. (Jossey-Bass: San Francisco)

Blacket D, Hamilton NA (1992) Analysis and recommendations. In 'Understanding farmer decision making on land use'. (Eds D Blacket, G Hamilton) pp. 13-33. (Queensland Department of Primary Industries: Brisbane)

Clewett JF, Clarkson NM, George DA, Ooi S, Owens DT, Partridge IJ, Simpson GB (2003) Rainman StreamFlow (version 4.3): a comprehensive climate and streamflow analysis package on CD to assess seasonal forecasts and manage climatic risk. Information series QI03040, Department of Primary Industries Queensland, Brisbane.

Collinson M (2000) The application of FSR to technology development. In 'A history of farming systems research'. (Ed. M Collinson) pp. 95-129. (FAO and CABI: Wallingford) 
Cramb RA, Catacutan D, Culasero-Arellano Z, Mariano K (2007) The 'Landcare' approach to soil conservation in the Philippines: an assessment of farm-level impacts. Australian Journal of Experimental Agriculture 47, 721-726. doi: 10.1071/EA06049

Dalal RC, Mayer RJ (1986) Long-term trends in fertility of soils under continuous cultivation and cereal cropping in Southern Queensland. I. Overall changes in soil properties and trends in winter cereal yields. Australian Journal of Soil Research 24, 265-279. doi: 10.1071/ SR9860265

Dalal RC, Weston EJ, Strong WM, Lehane KJ, Cooper JE, Wildermuth GB, King AJ, Holmes CJ (2004a) Sustaining productivity of a Vertosol at Warra, Queensland, with fertilisers, no-tillage, or legumes. 7. Yield, nitrogen and disease-break benefits from lucerne in a two-year lucernewheat rotation. Australian Journal of Experimental Agriculture 44, 607-616. doi: 10.1071/EA02115

Dalal RC, Weston EJ, Strong WM, Probert ME, Lehane KJ, Cooper JE, King AJ, Holmes CJ (2004b) Sustaining productivity of a Vertosol at Warra, Queensland, with fertilisers, no-tillage, or legumes. 8. Effect of duration of lucerne ley on soil nitrogen and water, wheat yield and protein. Australian Journal of Experimental Agriculture 44, 1013-1024. doi: 10.1071/EA03166

Dalgleish NP, Foale MA (Eds) (1998) 'Soil matters. Monitoring soil water and nutrients in dryland farming.' (CSIRO Agricultural Production Systems Research Unit: Toowoomba, Qld)

Department of Employment, Economic Development and Innovation (2009) Prospects for Queensland's primary industries 2008-09. (Queensland Government: Brisbane) Available at www.dpi.qld.gov.au/cps/rde/dpi/ hs.xs1/16_9795_ENA_HTML.htm [Verified 8 May 2009]

Ewing MA, Flugge F (2004) The benefits and challenges of crop-livestock integration in Australian agriculture. In 'New directions for a diverse planet. Proceedings of 4th international crop science congress, Brisbane, Australia. Section 6, 12th Australian agronomy conference, crop-livestock integration'. (The Regional Institute: Gosford, NSW) (CD-ROM)

Lawrence DN (2006) Learning as participation in grains research, development and extension in Australia. $\mathrm{PhD}$ Thesis, Griffith University, Brisbane. Available at http://www4.gu.edu.au:8080/adtroot/public/adt-QGU20070118.111610/ [Verified 8 July 2009]

Lawrence DN, Cawley ST, Hayman PT (2000) Developing answers and learning in extension for dryland nitrogen management. Australian Journal of Experimental Agriculture 40, 527-539. doi: 10.1071/ EA99147

Lewin K (1947) Frontiers in group dynamics. Human Relations 1, 5-41.

Littleboy M, Silburn DM, Freebairn DM, Woodruff DR, Hammer GL (1989) PERFECT, a computer simulation model of productivity, erosion, to evaluate conservation techniques. Queensland Department of Primary Industries Bulletin QB 89005. Brisbane.

Llewellyn RS, Pannell DJ, Lindner RK, Powles SB (2005) Targeting key perceptions when planning and evaluating extension. Australian Journal of Experimental Agriculture 45, 1627-1633. doi: 10.1071/ EA04102
Lloyd DL (2004) Successful integration of pastures in farming systems. In 'Pastures in farming systems - meet the challenge. Proceedings of the 19th annual conference of the Grassland Society of NSW Inc., Tamworth, NSW'. (Eds SP Boschma, GM Lodge) pp. 87-92. (The Grassland Society of NSW: Tamworth)

Lloyd DL, Johnson B, O'Brien SM (2007a) Sown pasture grasses and legumes for marginal cropping lands in southern inland Queensland. Tropical Grasslands 41, 164-173.

Lloyd DL, Johnson B, O’Brien SM, Roesner EA, Boschma SP, Williams RW (2007b) 'LeyGrain ${ }^{\mathrm{TM}}$ pastures in farming systems - sustaining profit and the environment. Workshop package, Northern Grainbelt of Australia.' (Queensland Department of Primary Industries and Fisheries and the Grains Research and Development Corporation: Toowoomba)

Pannell DJ, Marshall GR, Barr N, Curtis A, Vanclay F, Wilkinson R (2006) Understanding and promoting adoption of conservation practices by rural landholders. Australian Journal of Experimental Agriculture 46, 1407-1424. doi: 10.1071/EA05037

Puckridge DW, French RJ (1983) The annual legume pasture in cereal-ley farming systems in southern Australia: a review. Agriculture Ecosystems \& Environment 9, 229-267. doi: 10.1016/0167-8809(83)90100-7

Reeves TG (1987) Pastures in cropping systems. In 'Temperate pastures, their production, use and management'. (Eds JL Wheeler, CJ Pearson, GE Robards) pp. 501-515. (CSIRO Publishing: Melbourne)

Revans R (1982) 'The ABC of action learning.' (Chartwell-Bratt: London)

Revans R (1997) The learning equation. In 'Action learning at work'. (Ed. A Mumford) pp. 21-22. (Gower: Aldershot, UK)

Strahan R, Scott F (2004) A decision aid to assess the economic implications of ley pastures in crop rotations. In 'Proceedings of the 19th annual conference of the Grassland Society of NSW Inc.'. (Eds S Boschma, G Lodge) pp. 78-81. (The Grassland Society of New South Wales: Tamworth)

Strong WM, Dalal RC, Weston EJ, Lehane KJ, Cooper JE, King AJ, Holmes CJ (2006) Sustaining productivity of a Vertosol at Warra, Queensland, with fertilisers, no-tillage or legumes. 9. Production and nitrogen benefits from mixed grass and legume pastures in rotation with wheat. Australian Journal of Experimental Agriculture 46, 375-385. doi: 10.1071/EA05007

Thomas GA, Titmarsh GW, Freebairn DM, Radford BJ (2007) No-tillage and conservation farming practices in grain growing areas of Queensland - a review of 40 years of development. Australian Journal of Experimental Agriculture 47, 887-898. doi: 10.1071/EA06204

Vanclay F (2004) Social principles for agricultural extension to assist in the promotion of natural resource management. Australian Journal of Experimental Agriculture 44, 213-222. doi: 10.1071/EA02139

Winter WH, Doyle PT (2008) Increased profitability and social outcomes from livestock in smallholder crop-livestock systems in developing countries: the ACIAR experience. Australian Journal of Experimental Agriculture 48, 799-805. doi: 10.1071/EA08013

Manuscript received 30 December 2008, accepted 18 May 2009 


\section{Appendix 1. Workshop group locations}

Maranoa-Balonne: Begonia, Condamine, Yalebone Creek, Donnybrook, Dulacca, Hodgson, Meandarra, Miles, Roma, St George, Surat, Wyambeh.

Border Rivers: Billa Billa, East Moonie/Pipeclay Creek, Goondiwindi, Goondoola, Inglewood, Millmerran, Moonie, Nindigully, Weangallon, Stanthorpe, Talwood, Teelba, Texas, Toobeah.

Private agronomist workshop: Goondiwindi.

\section{Appendix 2. On-farm activities and field days}

\section{Activities}

Tropical grass and temperate and/or tropical legume species comparisons, including the use of phosphorus and sulfur fertiliser with legumes, as follows:

Goondoola group, two properties - caatinga stylo (Stylosanthes seabrana), desmanthus (Desmanthus virgatus), Bisset creeping blue grass (Bothriochloa insculpta), Floren blue grass (Dichanthium aristatum) and leucaena (Leucaena leucocephala).

Talwood, Goondiwindi, St George groups, four properties - Medway pertusa (Bothriochloa pertusa).

Teelba group, one property - caatinga stylo, desmanthus, Bisset creeping blue grass, Floren blue grass.

East Moonie group, three properties - medics (Medicago spp.) into old, established bambatsi panic (Panicum coloratum) pasture, various grasses with desmanthus and caatinga stylo, yellow serradella (Ornithopus compressus).

Moonie group, three properties - various grasses and legumes.

Yalebone Creek group, one property - caatinga stylo into ripped buffel grass (Cenchrus ciliaris) pasture.

Donnybrook group, five properties - leucaena, desmanthus, medic into rundown buffel grass.

Begonia group, two properties - various grasses and legumes, sulla (Sulla coronarium).

\section{Field days}

Goondoola group, two properties - sown pasture development in 2006-07.

Billa Billa group, one property - pasture management.

Condamine group, three properties - sown pasture development in 2007-08. 
Appendix 3. Workshop evaluation template (workshop number in parentheses)

Q1. How strongly do you agree or disagree with these statements about the LeyGrain workshop? (Please circle one number) [Each specific question was asked after workshops within the sections designated in parentheses (see 'The LeyGrain package')]

\begin{tabular}{|c|c|c|c|c|c|}
\hline & Strongly disagree & Disagree & Unsure & Agree & Strongly agree \\
\hline Is a good investment of industry funds $(1-4)$ & 1 & 2 & 3 & 4 & 5 \\
\hline Had an impact on my learning (1-3) & 1 & 2 & 3 & 4 & 5 \\
\hline Helped me interact and learn from others' experiences (1-4) & 1 & 2 & 3 & 4 & 5 \\
\hline Has influenced me to change my farming practices $(1,2)$ & 1 & 2 & 3 & 4 & 5 \\
\hline Provided me with an understanding of the roles of pastures (1) & 1 & 2 & 3 & 4 & 5 \\
\hline Will help improve the sustainability of my farming practices (1) & 1 & 2 & 3 & 4 & 5 \\
\hline Will help improve the profitability of my farming practices (1) & 1 & 2 & 3 & 4 & 5 \\
\hline Provided me with too much information (1) & 1 & 2 & 3 & 4 & 5 \\
\hline Improved my knowledge of grass and legume species (2) & 1 & 2 & 3 & 4 & 5 \\
\hline Helped me understand the importance of seed quality (2) & 1 & 2 & 3 & 4 & 5 \\
\hline \multicolumn{6}{|l|}{ Provided me with enough information on how to sow pastures (2) } \\
\hline Improved my skills in managing the fallow between pasture and crop (4) & 1 & 2 & 3 & 4 & 5 \\
\hline Utilised a useful workbook (4) & 1 & 2 & 3 & 4 & 5 \\
\hline The workshop provided me with too little information (4) & 1 & 2 & 3 & 4 & 5 \\
\hline The workshop provided me with too much information (4) & 1 & 2 & 3 & 4 & 5 \\
\hline \multicolumn{6}{|l|}{ The LeyGrain workshop improved my knowledge to: } \\
\hline Understand how pastures could improve my cropping system (1) & 1 & 2 & 3 & 4 & 5 \\
\hline Understand how pastures could improve my soils (1) & 1 & 2 & 3 & 4 & 5 \\
\hline Understand how pastures could improve the environment (1) & 1 & 2 & 3 & 4 & 5 \\
\hline \multicolumn{6}{|l|}{ The LeyGrain workshop improved my ability to: } \\
\hline Select suitable grasses for my property (2) & 1 & 2 & 3 & 4 & 5 \\
\hline Select suitable legume pastures for my property (2) & 1 & 2 & 3 & 4 & 5 \\
\hline
\end{tabular}

Questions asked after workshops

[Each comment was asked after workshops within the sections designated in brackets (see 'The LeyGrain package')]

Area of pasture sown 5 years ago..........Now........5 years time.......(specify acres or hectares) $(1,2)$

Reasons for increase or decrease in area of pasture sown $(1,2)$

After doing the LeyGrain workshop, what will you do differently? (1-3)

Are there any comments you would like to make about the LeyGrain workshop or the process used? (1-4)

My livestock management could be described as (3): Please circle the appropriate response

average good very good

My feed year budgeting could be described as (3): Please circle the appropriate response

non existent some planning well planned

My pastures would be described as (3): Please circle the appropriate response

poor condition average condition good condition

I have found the LeyGrain workshop series (4): Please circle the appropriate response

not very helpful helpful very helpful

I have read the Reference manual and found it to be (4): Please circle the appropriate response not very useful useful very useful 